\title{
Muslim physicians and palliative care: attitudes towards the use of palliative sedation
}

\author{
George Muishout $^{1}$ (D) Hanneke W. M. van Laarhoven ${ }^{2} \cdot$ Gerard Wiegers $^{1} \cdot$ Ulrike Popp-Baier $^{1}$
}

Received: 16 November 2017 / Accepted: 26 April 2018 / Published online: 8 May 2018

(C) The Author(s) 2018

\begin{abstract}
Background Muslim norms concerning palliative sedation can differ from secular and non-Muslim perceptions. Muslim physicians working in a Western environment are expected to administer palliative sedation when medically indicated. Therefore, they can experience tension between religious and medical norms.

Objective To gain insight into the professional experiences of Muslim physicians with palliative sedation in terms of religious and professional norms.

Design Interpretative phenomenological study using semi-structured interviews to take a closer look at the experiences of Muslim physicians with palliative sedation. Data were recorded, transcribed and analysed by means of interpretative phenomenological analysis (IPA).

Participants Ten Muslim physicians, working in the Netherlands, with professional experience of palliative sedation.

Results Two main themes were identified: professional self-concept and attitudes towards death and dying. Participants emphasized their professional responsibility when making treatment decisions, even when these contravened the prevalent views of Islamic scholars. Almost all of them expressed the moral obligation to fight their patients' pain in the final stage of life. Absence of acceleration of death was considered a prerequisite for using palliative sedation by most participants.

Conclusions Although the application of palliative sedation caused friction with their personal religious conceptions on a good death, participants followed a comfort-oriented care approach corresponding to professional medical standards. All of them adopted efficient strategies for handling of palliative sedation morally and professionally. The results of this research can contribute to and provide a basis for the emergence of new, applied Islamic ethics regarding palliative sedation.
\end{abstract}

Keywords End of life $\cdot$ Intercultural care $\cdot$ Islam $\cdot$ Muslim physicians $\cdot$ Palliative sedation

\section{Introduction}

With a current percentage of roughly $5 \%$ with an expected increase in the coming decades, the presence of Muslims in Europe is a relatively small but permanent factor in European countries [1]. In these countries, a growing proportion of Muslims, second- and third-generation descendants of

George Muishout dickerie@yahoo.com

1 Department of History, European Studies and Religious Studies, Amsterdam School for Historical Studies, University of Amsterdam, Amsterdam, The Netherlands

2 Department of Medical Oncology, Cancer Center Amsterdam, Academic Medical Center, University of Amsterdam, Amsterdam, The Netherlands immigrants from Islamic countries, train as physicians. In their work, these Muslims are supposed to respect professional Western medical standards, like alleviating suffering and acting after informed consent only. However, these standards could potentially conflict with Islamic norms and values $[2$, 3]. Previous studies have shown that personal religious orientations could play a role regarding attitudes and behaviour towards medical treatment around the end of life. This might be particularly true of Muslims, since a strong relationship between their religious ideas and daily practices is known to exist among many of them [4]. Thus, recent research suggests that physicians with a religious background are more inclined to reject treatment options which they believe may accelerate the dying process and are less likely to discuss these options with their patients [5-7]. Within a global trend of increasing cultural and religious diversity with patient-orientated palliative care, in which Muslims will not only act as patients but 
also as care providers, it is important to develop an understanding of what this means for Muslim physicians [8].

One of the areas of potential tension between professional Western medical standards and Islamic norms is the use of sedatives in a palliative setting. Terminally ill patients often have to contend with severe symptoms like pain and nausea. In many cases, these symptoms can be treated effectively by regular medication $[9,10]$. However, despite progress in the field of palliative care, a category of symptoms which cannot be successfully treated by regular means still remains [11, 12]. In the Netherlands these cases, defined as intolerable suffering of the dying patient, caused by one or more refractory symptoms, can be alleviated by the use of palliative sedation [13, 14]. In the Netherlands, palliative sedation, which has been approved by the Royal Dutch Medical Society (KNMG), is regarded as normal medical practice, institutionalized by law $[15,16]$. Among its main features are proportional not lifeshortening application, a focus on comfort and a life expectancy of less than 14 days under continuous sedation [17].

Although as yet no Islamic religious discourse about palliative sedation exists, it is a hotly debated issue in Muslim circles $[18,19]$. A major cause of controversy is the involvement of a moral debate in the central question: What is a good death? Qualitative research by De Graaff et al. has indicated that the desire to appear before God with a clear mind is one of the elements of 'a good death' for Muslim patients in the Netherlands [20, 21]. This proviso would, they suggest, be hindered by palliative sedation. If this condition of a good death is shared by Muslim physicians, their acquiescence could imply an area of tension with medical professional standards in which striving for the absence of, or at least for reduction in, symptoms is the norm.

To our knowledge, no empirical study has been made of the views of Muslim physicians on palliative sedation. This study aims to assess how Muslim physicians imbue ethical questions about palliative sedation with meaning within the scope of their professional identity. Our research question was as follows: 'In the context of palliative sedation, how do Dutch Muslim physicians reconcile their religious scruples about a good death and professional standards of professional care prevalent in the Netherlands?'

\section{Research area and methodology}

The main focus in this study is the way in which Muslim physicians assign meaning to their experiences with palliative sedation in a general palliative care setting. Those eligible were Muslim physicians with work-related experience with palliative sedation in general palliative care. Such personal subjective perspectives require a qualitative approach. To obtain an adequate methodical response to this problem, interpretative phenomenological analysis (IPA) has been used. Central to IPA is its phenomenological starting point which presupposes that all entities manifest themselves through and are understood by personal experience. By aiming to make sense of this experience and to situate it in a wider socialcultural context, the researcher engages in an active process of interpretative analysis [22]. To do justice to individual experience, every case is carefully studied in its own right before making any comparison with other cases [23].

\section{Participants}

Their selection was made according to the principles of purposeful sampling [24]. Those eligible were Muslim physicians with work-related experience of palliative sedation in general palliative care. Fifteen appropriate participants were identified, all of whom were willing to co-operate. With one exception, all had been fully educated and trained in the Netherlands. Three of them were already part of the professional network of the research team. Six were found through Internet search on web pages of Dutch general practices and hospitals. The names of potential participants were selected by association with Muslim names and subsequently approached by phone or e-mail. The remaining six were suggested by participants who had already been recruited in the aforementioned process. Ten participants in all were finally interviewed: eight male, two female. All had a Sunni background and were practising Muslims (Table 1). Thematic saturation was reached after eight interviews and, after conducting another two interviews, we stopped.

\section{Research team}

The first author (GM) recruited the participants and conducted all the interviews. The research team contained expertise in the fields of clinical oncology and palliative care $(\mathrm{HvL})$, the ethics of Islam (GM, GW), the psychology of religion (UP-B) and religious studies (HvL, GW, UP-B).

\section{Data collection}

The interviews were conducted using a semi-structured interview. Participants were asked to think of a case of palliative sedation in which they had been professionally involved. This served as a starting point to explore thoughts, feelings and motives by means of prompts. The questionnaire stimulated and allowed the participants to articulate their conceptual understanding about palliative sedation (Table 2). All interviews took place between February and October 2016. Three were conducted in a home environment, three in the workplace, one in a restaurant and one at the office of a foundation. Care was taken that the place was quiet enough to ensure an undisturbed 
Table 1 Participant characteristics

\begin{tabular}{|c|c|c|c|c|}
\hline $\begin{array}{l}\text { Anonymous } \\
\text { name }\end{array}$ & $\begin{array}{l}\text { Birth } \\
\text { year }\end{array}$ & Sex & Type of physician & $\begin{array}{l}\text { Ethnic } \\
\text { background }\end{array}$ \\
\hline Yusuf & 1977 & Male & $\begin{array}{l}\text { Trainee general } \\
\text { practitioner }\end{array}$ & Moroccan \\
\hline Talha & 1985 & Male & $\begin{array}{l}\text { General } \\
\text { practitioner }\end{array}$ & Moroccan \\
\hline Omar & 1984 & Male & Trainee neurologist & Moroccan \\
\hline Anwar & 1983 & Male & Trainee internist & Turkish \\
\hline Amin & 1959 & Male & Geriatrician & Afghan \\
\hline Khalid & 1974 & Male & Anaesthetist & Moroccan \\
\hline Farid & 1980 & Male & $\begin{array}{l}\text { Acute medicine } \\
\text { specialist }\end{array}$ & Moroccan \\
\hline Nabila & 1977 & Female & $\begin{array}{l}\text { General } \\
\text { practitioner }\end{array}$ & Moroccan \\
\hline Muhammad & 1970 & Male & $\begin{array}{l}\text { General } \\
\text { practitioner }\end{array}$ & Turkish \\
\hline Khadidja & 1982 & Female & Trainee internist & Moroccan \\
\hline
\end{tabular}

Participants are listed by chronology of the interview date interview. All interviews were recorded after informed consent. Anonymity was guaranteed. They lasted between 45 and 100 minutes and were transcribed verbatim.

\section{Data analysis and validation}

The initial stage of the analysis consisted of repeated intensive readings of one of the interviews while exploratory comments were noted by three researchers (GM, HvL and GW). The results were discussed in a plenary session with special attention to biases and assumptions due to our different positionalities (a.o. age, profession, cultural and religious background). The first researcher (GM) applied the same technique to two other interviews which were subsequently annotated with written feedback by the research team and discussed in another plenary meeting. In the second stage, the exploratory comments on one of the interviews were used by the first researcher (GM) to develop emerging themes representing a conceptual understanding which reflected the experience of the participant. In the third stage, he compiled a map of themes and their relationships, highlighted by illustrative quotes and correlated them by distinguishing between main themes and subthemes, thereby creating super-ordinate themes. This process was subsequently repeated in each individual interview. During the second and third stage, GM kept a research diary in which he noted the underlying rationales for the interpretations made. What emerged from this was our understanding that the perception of an insoluble tension between Western medical standards and Islamic values is a familiar theme among some Muslim patients and their families which triggered us during the design phase of this study. Looking back in a reflective mode, we are confident that this had no influence on our interview model and the manner of interviewing, which was purely facilitating. After analysing all the transcripts a draft, representing the study in its entirety was composed and discussed in the team. After written feedback, the final map, which served as the basis for the presentation of the results, was drawn up. During all our team meetings, critical reflexivity has had high priority. For the written account of the study, we followed the COREQ guidelines, a checklist for qualitative research [25].

\section{Results}

Depending on their professional experiences, participants reflected on their interactions with both non-Muslim and Muslim patients. They also expressed their personal views on a good death. Two main themes consisting of ten subthemes were distinguished: (I) professional self-concept and (II) attitudes towards death and dying. The second was then sub-divided into (II a) Islamic perspectives on a good death and the dying process and (II b) palliative sedation in relation to Islamic perspectives on a good death. Whereas the first principal theme addresses the identity markers of the professional and religious identity of the participants, the second focuses on the tension between comfort-oriented care versus religious issues raised by palliative care. Both themes describe personal inner tension and tension on the level of interaction with patients and their network. The super-ordinate themes, subthemes and illustrative sample participant quotations translated into English are summarized in Table 3 (quotations 1 up to 9) and Table 4 (quotations 10 up to 28) and will be explained below. 
Table 2 Example of the interview questions

Personal information/background

Year of birth

Sex

Medical education

Motivation to study medicine

Current employment

Professional experience

Main questions

1. Would you like to think of a case in which palliative sedation was used?

2. What was (in this case) the reason to commence sedation?

3. How was the decision to sedate made? ... ..Who were involved? ...... What was the response?

4. Can you tell me how you communicated the suggestion for palliative sedation? Who were involved (present)?

5. What was the response to your suggestion to switch to palliative sedation (patient / family)?

6. Can you describe its course (until death?)

7. How did those who were closely involved with the patient (family, relatives, etc.) respond?

8. Can you tell me about the contact with those involved after the patient died?

*(Questions 1 to 8 can be applied to multiple cases.)

Palliative sedation and good death

9. What do you see as the objective of palliative sedation?

10 . What do you mean by a good death ... for a patient ...for his / her family (for yourself)?

11. What do you feel about pain relief (in the form of medication) at the end of life? (Would you use it yourself if you were a patient ... based on what considerations.)

12. How do you think the application of pain management relates to a good death, and what part does palliative sedation play?

13. What, in your opinion, does the use of palliative sedation at the end of life mean for the 'quality' of life?

Religious background

14. In what kind of religious environment did you grow up (home \& environment)?

15. Do you consider yourself a Muslim? Can you tell me something about that?

16. May I ask if you consider yourself to belong to a certain branch of Islam?

17. What is the current role and meaning of your religion in your daily life?

18. What is the significance of religion in your professional life (as a physician)?

19. Do you think your beliefs play a role in the considerations and choices you make as a professional?

20. What do the pronouncements of imams or Islamic scholars mean to you?

21. Are there any of pronouncements about palliative sedation to guide you?

Are there things you find important to say but have not been addressed?

\section{I: professional self-concept}

\section{Primacy of individual moral decision as a physician}

With the understanding that Islamic legal views on palliative sedation are still in an embryonic stage or that some of the participants were unaware of them, all considered their own informed views and opinions took first place in professional decision-making. Although some participants expressed appreciation of the carefully substantiated views of religious scholars and stated that these should be taken very seriously, nearly all said that own practice-based decisions should always take precedence (quote 1). One participant, from an Islamic country in which he had begun his professional career as a physician, thought that his role as a decision maker required divine legitimization. He thereby implied that, in his view, medical ethical assessment by Islamic scholars was not necessary when making decisions about complex treatment (quote 2). The opportunity for a religious authority to influence treatment decisions was presented in a focus on patient centrality (quote 3 ). Moreover, an instrumental need was felt for normative guidance in the form of clear statements from Islamic scholars to facilitate joint decision-making on palliative sedation (quote 4).

\section{Alleviating suffering as moral duty}

Eight participants were very outspoken about the medical professional imperative to take measures to relieve pain (quote 5). For the vast majority of the interviews, this view ran parallel to the patients and family's preferences. Three of them stressed that pain should always be alleviated, regardless of whether or not someone is dying (quote 6). In one instance, a saying of the Prophet Muhammad was quoted to underpin the call to fight pain religiously (quote 7).

\section{Pain relief as professional medical task}

A different way of framing pain management was to focus on patient rights. Unquestionably, it was felt that there was a professional obligation to comply with a patient's request for pain relief (quote 8). Some positioned themselves as guardians of a patient's right to self-determination should the family or an imam intervene (quote 9).

\section{II: attitudes towards death and dying}

\section{II a: Islamic perspectives on a good death and the dying process}

Importance of awareness Four participants addressed the religious significance of having a clear mind in the face of death. The question - to our knowledge not so far addressed in any 
Table 3 Overview of theme 1, including quotations 1 up to 9

\begin{tabular}{|c|c|c|}
\hline Super-ordinate theme & Subtheme & Quote \\
\hline \multicolumn{3}{|c|}{ I: professional self-concept } \\
\hline & \multirow[t]{4}{*}{$\begin{array}{l}\text { Primacy of individual moral } \\
\text { decision as a physician }\end{array}$} & $\begin{array}{l}\text { 1: 'However, an Imam or Islamic scholar cannot simply dictate } \\
\text { to me what I should do, because a physician is personally } \\
\text { responsible for his own, Islamically as well right? Because } \\
\text { you take action as you see fit'. (Yusuf) }\end{array}$ \\
\hline & & $\begin{array}{l}\text { 2: 'I am also a human being, but I think that we as Muslim or as } \\
\text { physician are permitted by God to make a decision'. (Amin) }\end{array}$ \\
\hline & & $\begin{array}{l}\text { 3: 'If you are treating a patient to whom the imam's opinion is } \\
\text { important. In that case, in the interests of the patient you } \\
\text { have to pay heed to it'. (Anwar) }\end{array}$ \\
\hline & & $\begin{array}{l}\text { 4: 'You say: well now, what is said about this in the literature or } \\
\text { what sort of pronouncements have a bearing on it. And, well } \\
\text { that this or that applies to the person dear to you. We can go } \\
\text { ahead and do this. Nothing is standing in our way. I think } \\
\text { that this would clear up a great deal of uncertainty'. (Omar) }\end{array}$ \\
\hline & \multirow[t]{4}{*}{$\begin{array}{l}\text { Alleviating suffering } \\
\text { as moral duty }\end{array}$} & $\begin{array}{l}\text { 5: 'Yes and if a patient is truly suffering physically, this is obvious } \\
\text { from the state he is in, from his facial expressions, and then, } \\
\text { of course, you have to do something about it'. (Farid). }\end{array}$ \\
\hline & & $\begin{array}{l}\text { 6: 'I think you have to see pain management as a separate issue. } \\
\text { It is something detached from the stage of life a person is in. } \\
\text { In short, if someone needs it then it must be used'. (Anwar) }\end{array}$ \\
\hline & & $\begin{array}{l}\text { 7: 'I see it as 'li kulli dāin dawā' (every disease has a cure, GM) } \\
\text { [23], that's what I think. Am I interpreting this properly? }\end{array}$ \\
\hline & & $\begin{array}{l}\text { I'm not really sure. But I see a eh a disease, eh and I interpret } \\
\text { it as such. So, if there's a dawä' (medicine, GM) for it, then } \\
\text { I see it as my calling to go ahead and use it like this'. (Talha) }\end{array}$ \\
\hline & \multirow[t]{2}{*}{$\begin{array}{l}\text { Pain relief as professional } \\
\text { medical task }\end{array}$} & $\begin{array}{l}\text { 8: 'Well then, as I have already said, giving a patient pain relief is } \\
\text { part and parcel of your duties as a physician'. (Khalid) }\end{array}$ \\
\hline & & $\begin{array}{l}\text { 9: 'As far as I am concerned, as a physician I am there to put the } \\
\text { patient first and also to protect them, and in this pain } \\
\text { relief is a must'. (Khadidja) }\end{array}$ \\
\hline
\end{tabular}

fatwa - was posed whether it was allowed to deprive someone of the opportunity to fulfil their obligation towards God to observe the five daily prayers by a permanent reduction in awareness until death occurs (quote 10). For one participant, the possibility to pronounce the Islamic Creed appeared to be important to dying in a state of awareness (quote 11). However, the need for awareness to express the Islamic Creed was debunked by another participant who evoked God's omnipotence, which encompasses the ability to communicate with whomsoever one wishes under any circumstances (quote 12). Other concerns about dying consciously lay in the desire to be able to focus completely on God as the ultimate way to face death (quote 13).

Expiation of sins through suffering The idea of suffering to improve one's position in the hereafter was raised by three participants. They pointed out that this well-known theological argument was used by patients' families in their dismissive attitude towards palliative sedation (quote 14). Two participants emphasized that this view on suffering opposes the very nature of being a physician (quote 15 ). In one case, a participant described his dilemma about how the blessing of suffering in the Islamic tradition could be reconciled with pain management (quote 16).

Medical intervention until death Four participants mentioned the view prevalent among Muslims that all medical means should be deployed until the very end of life. Three cases concerned Muslim patients who were no longer able to communicate with their families. In two of them, there existed strong family resistance against palliative care. This viewpoint translated itself dramatically into an uncompromising attitude of the patient's family towards the attending physician the moment he proposed to make the transition from curative to palliative care (quote 17). This fierce resistance did not prevent the said two participants from steering towards comfort care anyway which was finally accepted. The Muslim idea of unlimited medical treatment was explained as a lack of understanding of palliative care, resulting in distorted religious images. This view was substantiated by referring to the unspecified nature of religious arguments (quote 18). However, this perception was nuanced by showing empathy for misunderstandings by referring to the negative impact of the threat of loss on a person's capacity for understanding (quote 19). 
Table 4 Overview of theme 2 , including quotations 10 up to 28

Super-ordinate theme Subtheme Quote

II: attitudes towards death and dying

II a: Islamic perspectives on a good death and the dying process
Importance of awareness

Expiation of sins through suffering

Medical intervention until death
10: '( $\ldots)$ that a person can't perform his prayers, yes that is also an argument. How should you tackle this situation? As physician you are the one in the position of responsibility. Because you have unnecessarily lowered the state of someone's consciousness'. (Yusuf)

11: 'And that at your very end your last words should be the shahāda (Islamic testimony of faith, GM). That you are in a state to be able to pronounce this. Well, it's not clear what you are experiencing when you are sedated, how much of this you can absorb'. (Khalid)

12: 'And I don't think it matters to God whether you are awake, clear in the head, you are unconscious (...) If He wishes, He can make contact with you. So, who am I to say: if you are asleep you are not able to communicate with God or to recite the shahāda for Allah'. (Amin)

13: ' (...) that I can also concentrate as fully as possible on Allah, can pray, I would think that was wonderful. That my last words were Allah's words, you know, that would be the most wonderful of all, of course. Or to die as I prayed, I think that would be tremendous. Well, naturally, you can't do that if you are heavily sedated'. (Nabila)

14: 'What they have said to me is that suffering at this stage, that is very important. Because it can work as an act of atonement for the sins you have committed throughout your life. And, when it's all said and done, this is indeed an argument: to endure this now is good for him because he has a chance of going to Heaven, to Janna (Paradise, GM)'. (Omar)

15: 'Some ideas prevalent Islam say: suffering is a sort of penance, a means by which you can atone for your sins. But this clashes a bit with your own actions as a physician'. (Khalid)

16: 'It is a contradiction that someone who is suffering, um let's make no bones about it - um, should bear this with patience. Er, that they obtain blessings through this. We are aware of this. Therefore, I think: What should we do to accommodate it. You try being in my place when someone is suffering from cancer. One that has metastasized. And that person is told: Bear up, because this is a blessing and it can also be a blessing for you..... with every pang you feel your sins are being forgiven. There is no discomfort at all, says the Prophet, peace be unto him, if this is borne patiently, um, sins are forgiven [26]'. (Muhammad)

17: 'They wanted to do everything that could be done. Saying then: Allah decides whether he lives or dies from this. And if you have said: If we operate and he dies all the same, you have done your best but Allah had decided not the physician, not a human being (...) and had we not allowed this chance it would be tantamount to murder'. (Omar)

18 'Then indeed a specific hadìth (Traditions from the Prophet Muhammad, GM) or a certain āya (verse, GM) in the Koran, that somebody had once heard of is referred to. But nothing concrete, and it remains up in the air'. (Yusuf)

19: 'Well, many also believe that as the physician says: Yes, we are going to stop treatment as medically we have reached the end of the road (...) That is immediately translated as: euthanasia, an active ending of a life or pulling out the plug. It gives rise to so many misconceptions. It is, of course, very difficult to explain. When it's all said and done a person is 
Table 4 (continued)

\begin{tabular}{|c|c|c|}
\hline Super-ordinate theme & Subtheme & Quote \\
\hline & & $\begin{array}{l}\text { losing someone dear to them, and this makes explanations } \\
\text { very difficult'. (Anwar) }\end{array}$ \\
\hline & Giving the patient a chance & $\begin{array}{l}\text { 20: 'I think that everybody deserves a chance. I've sent someone } \\
\text { who is ninety to intensive care because I didn't think that his } \\
\text { case was hopeless'. (Anwar) }\end{array}$ \\
\hline & & $\begin{array}{l}\text { 21: 'I am absolutely convinced that I as a physician, a Muslim } \\
\text { doctor, must pull out all the stops. That you should never } \\
\text { give up easily on someone. This is the reason that you are } \\
\text { always just a little bit on the defensive side'. (Omar) }\end{array}$ \\
\hline \multirow[t]{7}{*}{$\begin{array}{l}\text { II b: palliative sedation in relation to } \\
\text { Islamic perspectives on a good death }\end{array}$} & $\begin{array}{l}\text { Palliative sedation as possibly } \\
\text { life-shortening }\end{array}$ & $\begin{array}{l}\text { 22: 'Often, after I had given an injection I have had to pronounce } \\
\text { life extinct. The thought frequently crossed my mind: well that's } \\
\text { a bit too much of a coincidence. Then I felt a little awkward, } \\
\text { I've thought: have I really not been doing something wrong?' } \\
\text { (Nabila) }\end{array}$ \\
\hline & & $\begin{array}{l}\text { 23: 'But then again, I think about my own situation, if I had } \\
\text { COPD and I knew there was medication, I would say: Begin } \\
\text { palliative sedation. I would also be thinking about my family, } \\
\text { about those closest to me'. (Farid) }\end{array}$ \\
\hline & & $\begin{array}{l}\text { 24: 'As Muslims we believe that of course there is a certain time } \\
\text { at which it will happen. Nothing you can do will make it a } \\
\text { second earlier or a second later. And this time is already fixed. } \\
\text { It's just that your mind wanders along these lines: I'm doing } \\
\text { something and if I didn't do it, the result would be different'. } \\
\text { (Muhammad) }\end{array}$ \\
\hline & $\begin{array}{l}\text { Proportionate use of } \\
\text { palliative sedation }\end{array}$ & $\begin{array}{l}\text { 25: 'I think that you have to adjust this discreetly. You must } \\
\text { always be aware of what you are doing. In other words, } \\
\text { that you do not overshoot the mark'. (Khalid) }\end{array}$ \\
\hline & & $\begin{array}{l}\text { 26: 'Certainly, just go ahead. I always compare it to a situation } \\
\text { in which a person has a bad slipped disc, and the nerve pain } \\
\text { is awful. As long, and I reiterate this over and over, it does } \\
\text { not speed death up or shorten the length of life, it can be } \\
\text { done'. (Nabila) }\end{array}$ \\
\hline & $\begin{array}{l}\text { Palliative sedation versus } \\
\text { cause of death }\end{array}$ & $\begin{array}{l}\text { 27: 'But in the eyes of many other people and if one is realistic } \\
\text { one can understand their point of view, someone does not eat, } \\
\text { does not drink'. (Amin) }\end{array}$ \\
\hline & & $\begin{array}{l}\text { 28: 'One matter I always think important is to explain to these } \\
\text { people is that she did not die because of the medicines. That } \\
\text { they, hum, go home understanding this. The woman had an } \\
\text { illness and she died from it. I was not the cause, it happened } \\
\text { to her. Now and then you can say that Allah has foreordained } \\
\text { that it be so'. (Omar) }\end{array}$ \\
\hline
\end{tabular}

Giving the patient a chance While dismissing negative attitudes of Muslims towards the discontinuation of treatment as a lack of understanding, two participants explained their own attitudes tally with those of their non-Muslim peers in being more inclined to make a supreme effort to ensure the possibility of recovery come what may (quote 20). Both supported their attitude by referring to their Muslim identity (quote 21).

\section{II b: palliative sedation in relation to Islamic perspectives on a good death}

Palliative sedation as possibly life-shortening The feeling of doing something morally wrong which emerged during their first professional experiences with palliative sedation was described by two participants (quote 22). One of the two adjusted her opinion after a literature review and conversing with colleagues. This led her to the conclusion that palliative sedation did not hasten death. The other adhered to his initial view. Nevertheless, he also stated that he would opt for palliative sedation should he personally suffer intolerably (quote 23 ). Another participant, who shared the view that palliative sedation hastened death, did show enthusiasm for the use of palliative sedation, because it alleviated the patient's suffering. For the moral justification of his decision, he relied on the doctrine of double effect. In this principle, a possible negative outcome - the patient's earlier death - is secondary to the primary positive goal: namely, pain relief [27]. He also stated that the positive views of Muslim scholars on palliative sedation of 
which he was aware were based on this idea. Nevertheless, he struggled with the potential impact of his own actions at the moment of death and his Muslim conviction that this moment is a matter of divine will (quote 24).

Proportionate use of palliative sedation The importance of the proportionate use of sedatives for symptom management was emphasized by seven participants (quote 25). For those of this mind, the absence of acceleration of death was defined as a prerequisite for the use of palliative sedation (quote 26).

Palliative sedation and cause of death The possible positive correlation between palliative sedation and the cause of death had been encountered by four participants. Although they emphasized that the physician did not intervene in the natural process of dying by recourse palliative sedation, they showed empathy towards non-professionals who did think that this was the case (quote 27). Particular relevance was attached to convincing the family of the deceased that palliative sedation was not the cause of death (quote 28).

\section{Discussion}

So far contemporary Islamic religious legal discourse on end-oflife issues has principally be confined to the context of brain death. Observation that brain death had occurred provided a legitimate argument for the withdrawal of life support or the harvesting organs. This outcome has led to the idea that, even while rejecting attitudes also still exist, Islam has taken a largely permissive stance towards these practices [28]. Attitudes of rejection can also be encountered among families of Muslim patients diagnosed brain-dead [29]. Still largely absent is a normative Islamic perspective on death and dying as a process, a step which seems essential to developing an Islamic understanding of palliative care and quality of life as death approaches. Despite its absence, Muslim physicians have to come to terms with this form of comfort-orientated care, as it is part of their daily medical professional practice [30].

The purpose of the present study was to explore how, in the context of palliative sedation, Dutch Muslim physicians come to terms with their religious views on a good death and that this might clash with standards of professional care prevalent in the Netherlands. An important point of departure in the professional self-concept of the participants was their attitude towards Islamic scholars in general. They stressed the priority of their own opinions, and their own professional responsibility. The absence of a corpus of fatwas on palliative sedation makes it hard to say if their position would be maintained if they were faced with seriously opposing viewpoints.

In fact, the relationship between Islam and sedation is an uncomfortable one, in which admissibility in classic Islamic legal sources is confined to a curative context only. Because it undermines the human capability to reason, the following statement attributed to the Prophet Muhammad is paramount: 'Every intoxicant (muskir) is forbidden' [31, 32]. None of our participants, who almost all considered alleviating the suffering of the dying patient a virtuous deed, mentioned this argument. Acquiescing in the influential Islamic code governing the medical and health ethics of the Islamic Organization of Medical Sciences (IOMS) and an individual Muslims scholar, one participant alluded to the 'doctrine of double effect' in which relieving suffering outweighs any potential hastening of the dying process [27, 33, 34]. This recourse to the doctrine of double effect is remarkable. Firstly because it seems diametrically opposed to the Islamic naturalistic inspired tradition; God is the 'owner' of the human body, custodian of man and administrator of his deeds [35]. Therefore, human life should be protected and not actively terminated by human intervention. Secondly, several studies indicate that palliative sedation, if applied carefully, does not actually hasten death [36, 37]. These points were underlined by most participants who mentioned proportionate, that is, non-death accelerating use of palliative sedation as the precondition for administering it.

Although alertness of mind as a personal marker for an ideal death was put forward by two participants, none of them had any moral objections against palliative sedation. One participant struggled with the particular question whether it was permitted to deprive Muslim patients of the possibility of performing their five daily prayers through continuous sedation until death in his capacity as a Muslim himself. The background to this dilemma seems to be a classical theme in Islamic jurisprudence. It discusses the catching up with lifelong daily mandatory prayers after return to consciousness. Opinions within the Islamic schools of law vary between the obligation to make them up or to not make them up at all [38]. In contrast, there is a clinical reality in which palliative patients are suffering from a delirium which may, in fact, be the rationale for starting palliative sedation [39]. In a broader perspective, the provocative question could be raised whether clouding one's conscience through palliative sedation should then still be considered an issue at all, for, even from an Islamic normative perspective, one might wonder whether performing the mandatory prayers apply to such patients since these are only considered a religious duty as long an adult Muslim possesses normal mental capacities [40].

The view known among Muslims which advocates unlimited use of curative therapies as 'the Islamic view' was qualified by participants as a misconception which can be traced to poor conceptual understanding of palliative care [41-43]. This opinion seems consonant with the 2015 decision of the Saudi Arabia-based Islamic Fiqh Academy (IFA) on the discontinuation of treatment, allowing this if three reliable physicians decide continuation will harm to the patient and will not improve his condition. Interestingly, this decision also provides a starting point for palliative care of Muslim patients by stating 
that the focus of treatment should shift to comfort care should treatment be discontinued [44].

The question to what extent the attitudes, perceptions and feelings of the participants of this study conducted in the Netherlands could be transferred to those of their Muslim (and non-Muslim) peers in a Western or non-Western setting is difficult to answer. Religious views of believers in the major religions of the world - including Islam - on end-of-life issues are characterized by a great diversity. This is due to all kinds of variables such as local legal standards, culture, social and political norms and the concomitant existence of different subgroups within larger religions [45, 46]. Comparative studies would be highly desirable. In the Dutch situation, for example, palliative sedation is embedded in a culture in which it is the standard treatment for refractory symptoms at the end of life. Since a physician is supposed to perform palliative sedation, it can therefore be argued that this could have implications for the way in which he/she relates translates religious and philosophical ideas into practice. Therefore, it would be particularly interesting to apply a similar research design as we used here to Muslim physicians in other countries, including those who work in Muslim majority countries.

None of the participants were specialized palliative care physicians (e.g. working in a hospice). It could be argued that limited clinical experience with palliative sedation combined with possible lack of or little formal training in palliative care coloured their experiences.

While acknowledging that detailed dilemmas about the administration of palliative care in general and palliative sedation in particular have barely so far been addressed by Islamic legal scholars, the results of this study could contribute to and provide a basis for the emergence of a system of applied, practical ethics which could be used by physicians, Muslim and non-Muslim spiritual healthcare professionals and Muslim religious scholars to support their decisions in their confrontations with palliative care. None of the participants were specialized palliative care physicians (e.g. working in a hospice). It could be argued that limited clinical experience with palliative sedation combined with possible lack of or little formal training in palliative care coloured their experiences. In our subsequent research project, we therefore consider discussing the results with the participants in group discussions. In this regard, it should be emphasized that the setting of this research is that of general palliative care and these results may not apply to specialist palliative care.

In conclusion, although the use of palliative sedation gives some rise to tension with religious conceptions of a good death among Muslim physicians, participants followed a comfort-oriented care approach consonant with professional medical standards. All of them demonstrated efficient strategies for handling of palliative sedation morally and professionally. Further elaboration on Islamic ethical perspectives on palliative care and palliative sedation would assist the process of medical decision-making to combine religious thought and medical professional practice.

\section{Strengths and limitations of this study}

Some strengths and limitations of our study must be acknowledged. The multidisciplinary composition of the research team can be regarded as a strength in a multi-perspective analysis of the data. Because our sample is limited to Muslim physicians in the Dutch context, the outcomes might be less applicable in other countries. Despite this drawback, results of this study are relevant because they offer an insider perspective on the way professional and religious identity relate to each other in the context of palliative care.

More detailed research into how other professionals with a Muslim background, like chaplains, nurses and Muslim patients and their families, deal with palliative care is needed to acquire a more comprehensive insight into the functioning of applied Islamic ethics at the end of life. That is for later. The results of the present research might provide tools for initiating a system of new, applied Islamic ethics governing palliative sedation.

Acknowledgements We thank all participants for taking part and for their valuable input that enabled us to do this study.

Authorship This study was designed by GM, HvL, GW and UP-B. After GM wrote the first draft, he discussed it with HvL, GW and UPB. All authors contributed to the subsequent versions and agreed, after review, to the final article.

\section{Compliance with ethical standards}

The Ethical Medical Review Committee of the Academic Medical Center declared that The Dutch Medical Research Involving Human Subjects Act (WMO) did not apply to this project. Therefore, their approval was not necessary.

Competing interests The authors declare that they have no competing interests.

Ethics and consent Medical Research Involving Human Subjects Acts (WMO) did not apply to this project.

Open Access This article is distributed under the terms of the Creative Commons Attribution-NonCommercial 4.0 International License (http:// creativecommons.org/licenses/by-nc/4.0/), which permits any noncommercial use, distribution, and reproduction in any medium, provided you give appropriate credit to the original author(s) and the source, provide a link to the Creative Commons license, and indicate if changes were made.

\section{References}

1. Pew Research Centre (2017) Europe's growing Muslim population. Pew Research Centre, Washington, DC 
2. Hunida EA, Muhammad MH, Elbushra AHM (2011) Disclosure of terminal illness of governing codes in 14 Islamic countries. J Med Ethics 37:472-475

3. Guven T (2010) Truth-telling in cancer: examining the cultural incompatibility argument in Turkey. Nurs Ethics 17:159-166

4. Antiel RM, Curlin FA, James KM, Sulmasy DP, Tilburt JC (2012) Dignity in end-of-life care: results of a national survey of U.S. physicians. J Pain Symptom Manag 44:331-339

5. Seal C (2014) (2010) The role of doctors' religious faith and ethnicity in taking ethically controversial decisions during end- of-life care. J Med Ethics 36:677-682

6. Cohen J, van Delden J, Mortier F, Lofmark R, Norup M, Cartwright C, Faisst K, Canova C, Onwuteaka-Philipsen B, Bilsen J, on behalf of the Eureld Consortium (2008) Influence of physicians' life stances on attitudes to end-of-life decisions and actual end of-life decision-making in six countries. J Med Ethics 34(4):247-253

7. Padela AI (2007) Islamic medical ethics: a primer. Bioethics 21: 169-187

8. Wiener L, McConnell DG, Latella et al (2013) Cultural and religious considerations in paediatric palliative care. Palliat Support Care 11:47-67

9. Georges JJ, Onwuteaka BD, Van der Heide A et al (2005) Symptoms, treatment and "dying peacefully" in terminally ill cancer patients: a prospective study. Support Care Cancer 13:160-168

10. Lo B, Rubenfeld G (2005) Palliative sedation in dying patients: "We turn to it when everything else hasn't worked". JAMA 294: $1810-1816$

11. De Graeff A, Dean M (2005) Palliative sedation therapy in the last weeks of life: a literature review and recommendations for standards. Palliat Med 10:67-85

12. Rietjes JAC, van Zuylen L, Van Veluw H et al (2008) Palliative sedation in a specialized unit for acute palliative care in a cancer hospital: comparing patients dying with and without palliative sedation. J Pain Symptom Manag 36(3):228-234

13. van Deijck RHPD, Krijnsen PCJ, Hasselaar JGJ et al (2010) The practice of continuous palliative sedation in elderly patients: a nationwide explorative study among Dutch nursing home physicians. J Am Geriatr Soc 58:1671-1678

14. Matersvedt LJ, Clark D, Ellershaw J et al (2003) Euthanasia and physician-assisted suicide: a view from an EAPC ethics task force. Palliat Med 17:79-101

15. Ten Have H, Welie JV (2014) Palliative sedation versus euthanasia: an ethical assessment. J Pain Manage 47:123-136

16. Griffiths J, Weyers H, Adams M (2008) Euthanasia and law in Europe, Oxford and Portland, pp 52-54

17. KNMG (2009) Richtlijn Palliatieve Sedatie. Utrecht

18. Kluge G, Brewster E, Kuipers S (2012) Waardig sterven, godsdienstvrijheid en het recht van de oudste zoon (Dying with dignity, religious freedom and the right of the eldest son). Medisch Contact 67:748

19. Choukat A, ter Meulen B, Van Widdershoven G (2013) Palliatieve sedatie voor moslims bezwaarlijk (Palliative sedation objectionable for Muslims). Medisch Contact:1550-1551

20. De Graaff FM, Francke AL, Van den Muijsenbergh METC et al (2010) 'Palliative care': a contradiction in terms? A qualitative study of cancer patients with a Turkish of Moroccan background, their relatives and care providers. BMC Palliative Care 9:19

21. Hendriks MP, Van Laarhoven HW, Van de Sande R et al (2012) Palliative care for an Islamic patient: changing frameworks. J Palliat Med 15:1053-1055

22. Larkin M, Watts S, Clifton E (2006) Giving voice and making sense in interpretative phenomenological analysis. Qual Res Psychol 3:102-120

23. Smith JA, Shinebourne P (2012) Interpretative phenomenological analysis. In: Cooper H, Paul M, Long D et al (eds) APA handbook of research methods psychology: vol. 2: research designs: quantitative, qualitative, neuropsychological, and biological. American Psychological Association, Washington, DC, pp 73-82

24. Palinkas LA, Horwitz SM, Green AG et al (2015) Purposeful sampling for qualitative data collection and analysis in mixed method implementation research. Admin Pol Ment Health 42(5):533-544

25. Tong A, Sainsbury P, Craig J (2007) Consolidated criteria for reporting qualitative research (COREQ): a 32-item checklist for interviews and focus groups. Int J Qual Health Care 19:349-357

26. The participant's quote seems to hint at the following narration about the Prophet Muhammad: 'No calamity afflicts a Muslim but that Allah expiates some of his sins because of it, even though it were the prick from a thorn.' See: Mīqā Abū Bakr Isma'îl Muhammad (1984) Ahkām al-Marīd fī al-Fiqh al-Islāmī, alIbadāt wa al-Aḥwāl al-Shakhșiyya. Maktabat Dār al-Bayyān, p 22

27. Braude $H$ (2012) Normativity unbound: liminality in palliative care ethics. Theor Med Bioeth 33:107-122

28. Padela AI, Arozullah A, Moosa E (2013) Brain death in Islamic ethico-legal deliberation. Bioethics 27(3):132-139

29. Khalid I, Hamad WJ, Khalid TJ et al (2012) End-of-life care in Muslim brain-death patients: a 10 year experience. Am J Hospice Palliat Med 30(5):413-418

30. Padela A, Mohiuddin A (2015) Ethical obligations and clinical goals in end-of-life care: deriving a quality-of-life construct based on the Islamic concept of accountability before god (Taklıf). Am J Bioeth 15(1):3-13

31. Al-Zuhayli M (2008) Aḥkām al-Takhdīr wa al-Mukhadirāt alTTibbiya wa al-Fiqhiyya. Majalla al-Jāmi'a li -1- 'Ulūm alIqtișādiya wa al-Qanūniya 24:749-775

32. Al-Sjanqīitī, bin Muhammad al-Mukhtār bin Ahmad Mazīd al-Jiknī (1994) Aḥkām al-Jirāḥa al-Ṭibbiya wa al-Athār al Mutarattiba 'alaihā. Maktabat al-Sahāāba:273-291

33. See: Article Sixty-three: "The following cases are examples of what is not covered by "mercy killing". http://islamset.net/ioms/ code2004/index.html Accessed at 4 Sep 2017

34. Al-Bār, M'A (2012) Al-Tadāwī Qurb Nihāyat al-Hayāt wa al-In'āsh al-Qalbī al Riawī. Paper presented on the $21^{\text {st }}$ cycle of the International Fiqh Academy

35. Aramesh K (2009) The ownership of human body: an Islamic perspective. J Med Ethics Hist Med 2:4

36. Maltoni M, Pittureri C, Scarpi E (2009) Palliative sedation therapy does not hasten death: results from a prospective multicenter study. Ann Oncol 20:1163-1169

37. Sykes N, Thorns A (2003) Sedative use in the last week of life and the implications for end-of-life decision making. Arch Intern Med 163:341-344

38. Wizarat al-Awqāf wa al-Shu'ūn al-Islamiyya - al-Kuwayt (1988) alMawsū a al-Fiqhiyya. part 11. Dhata al-Salāsil, Kuwait, p.110

39. Bush SH, Leonard MM, Spiller JA et al (2014) End-of-life delirium: issues regarding recognition, optimal management, and the role of sedation in the dying phase. J Pain Sympt Manage 48:215-230

40. AR b Sa ad (2006) Al-Jāmi li-l-Ahkām wa Șifat al-Ṣalāt al-Nabī. Maktabat Dār al Ālamī, p 25

41. Ahaddour C, Van den Branden S, Broeckaert B (2017) Attitudes and beliefs of Muslim women toward withholding and withdrawing life-sustaining treatments. Med Health Care and Philosophy

42. Sachedina A (2005) End-of-life: the Islamic view. Lancet 366:774-779

43. Zahedi F, Larijani B, Bazzaz JT (2007) End of life ethical issues and Islamic views. Iran J Allergy Asthma Immunol 6:5-15

44. Majallat al-Jāma a al-Fiqhī (2015) 33:273-274

45. Chakraborty R, El-Jawahri AR, Litzow MR et al (2017) A systematic review of religious beliefs about major end-of-life issues in the five major world religions. Palliative and Supportive Care 15:609-622

46. Saeed F, Kousar N, Aleem S, Khawaja O, Javaid A, Siddiqui MF, Holley JL (2015) End-of-life care beliefs among Muslim physicians. Am J Hosp Palliat Med 32:388-392 